\title{
IMPLEMENTASI MODEL MANAJEMEN BERBASIS SEKOLAH (MBS) PADA MADRASAH TSANAWIYAH SWASTA TPI TANJUNG PUTUS
}

\author{
Maulana Akbar Sanjani \\ Penulis adalah Dosen Sekolah Tinggi Keguruan dan Ilmu Pendidikan (STKIP) \\ Perguruan Tinggi Budidaya Binjai
}

\begin{abstract}
This research aims to find out how the implementation of school-based management model (MBS). The research was conducted at the Cape End TPI MTsS This study used a qualitative research. It is based on the consideration that this study revealed the implementation model of school-based management (SBM). Qualitative research is a research procedure that produces descriptive data in the form of words - words written or spoken of - people whose behavior can be understood. The subject of research directed to the search data from principals, vice-principals, teachers, and staff at the Cape End MTsS TPI. The data collection was obtained by observation, interview and document research. The findings of this study as follows: 1) the perception of the principal on MBS model application. 2) the pattern of school leadership in MBS. 3) application of management functions in the activities - activities pendidikan.4) MBS models in the improvement of education management.
\end{abstract}

Keywords : Self-concept, Assertive Behavior.

\section{PENDAHULUAN}

Manajemen berbasis sekolah (MBS) dapat diartikan sebagai model manajemen sekolah yang memberikan otonomi kepada sekolah dan mendorong pengambilan keputusan partisipatif yang melibatkan langsung semua warga sekolah dan masyarakat (stakeholder) yang dilayani, dengan tetap selaras dengan kebijakan nasional tentang pendidikan.

Manajemen berbasis sekolah merupakan salah satu jawaban pemberian otonomi daerah dibidang pendidikan dan telah di Undang-Undangkan dalam UU Nomor 20 Tahun 2003 tentang Sisdiknas pasal 51 ayat (1) yang berbunyi, "Pengelolaan Satuan Pendidikan Anak Usia Dini, pendidikan dasar, dan pendidikan menengah dilaksanakan berdasarkan standar pelayanan minimal dengan prinsip manajemen berbasis sekolah.

Manajemen Berbasis Sekolah (MBS) merupakan alternatif baru dalam pengelolaan pendidikan yang lebih menekankan kepada kemandirian dan kreativitas sekolah.indikator keberhasilan MBS yang harus dapat diukur dan dirasakan oleh para stakeholder pendidikan, adalah adanya peningkatan mutu pendidikan disekolah. MBS 
pada prinsipnya bertumpu pada sekolah dan masyarakat serta jauh dari birokrasi yang sentralistik. MBS berpotensi untuk meningkatkan partisipasi masyarakat, pemerataan, efesiensi serta manajemen yang bermutu di tingkat sekolah. Sekolah dalam hal ini menjadi lembaga mandiri dalam menetapkan kebijakannya, tetapi memiliki jaringan kerja dengan berbagai pihak yang dapat meningkatkan mutu kinerja manajemen.

Manajemen Peningkatan Mutu Berbasis Sekolah yang dikeluarkan oleh Direktorat Pendidikan Menengah Umum, Dirjen Dikdasemen,Depdiknas diungkapkan beberapa indikator yang menjadi karakteristik dari konsep MBS sekaligus merefleksikan peran dan tanggung jawab masing-masing pihak antara lain:

1. Lingkungan disekolah yang aman dan tertib

2. Sekolah memiliki misi dan target mutu yang ingin dicapai

3. Sekolah memiliki kepemimpinan yang kuat

4. Adanya harapan yang tinggi dari personil sekolah (kepala sekolah, guru dan staf lainnya, termasuk siswa) untuk berprestasi

5. Adanya pengembangan staf sekolah yang terus menerus sesuai tuntutan

6. Adanya pelaksanaan evaluasi yang terus menerus terhadap berbagai aspek akademik dan administratif, dan pemanfaatan hasilnya untuk penyempurnaan dan atau perbaikan mutu

7. Adanya komunikasi dan dukungan intensif dari orang tua siswa dan masyarakat lainnya. ${ }^{1}$

Dengan model Manajemen Berbasis Sekolah(MBS) yang efektif dapat memberi keuntungan, seperti:

1. Kebijakan dan kewenangan sekolah membaca pengaruh langsung kepada siswa, orang tua siswa dan guru

2. Membawa manfaat sumber daya lokal secara optimal

3. Keefektifan melakukan pembinaan peserta didik, seperti kehadiran, hasil belajar, tingkat pengulangan, tingkat putus sekolah, moral guru dan iklim sekolah

4. Adanya perhatian bersama untuk mengambil keputusan, memberdayakan guru, manajemen sekolah, rancang ulangan sekolah dan perbuatan perencanaan.

Dengan demikian keefektifan MBS akan terwujud jika saja pengelola pendidikan mampu memberdayakan stakeholder dalam menentukan kebijakan,

\footnotetext{
${ }^{1}$ Amiruddin Siahaan, dkk, Manajemen Pendidikan Berbasis Sekolah, (Ciputat : Quantum Teaching,2006),hlm, 32
} 
pengadministrasian dan inovasi kurikulum yang dilakukan sekolah. Asumsi dasar untuk menegakkan manajemen berbasis sekolah (MBS) sebagai alternatif pemberdayaan sekolah adalah dikarenakan model ini merupakan wujud dari reformasi pedidikan yang pada prinsipnya MBS bertumpu pada sekolah dan masyarakat serta jauh dari birokrasi yang sentralistik. Artinya model ini berpotensi untuk meningkatkan partisipasi masyarakat, pemerataan, efisiensi dan manajemen yang bertumpu pada tingkat sekolah, guru dan administrator yang professional.

Keterangan yang bertumpu pada sekolah merupakan inti dari MBS yang dipandang memiliki tingkat efektivitas tinggi serta memberikan beberapa keuntungan:

1. Kebijakan dan wewenang sekolah membawa pengaruh langsung kepada peserta didik, orang tua dan guru

2. Bertujuan bagaimana memanfaatkan sumber daya local

3. Efektif dalam melakukan pembinaan peserta didik seperti kehadiran, hasil belajar, tindak pengulangan, tingkat putus sekolah, moral guru, dan iklim Sekolah

4. Adanya perhatian bersama untuk mengambil keputusan, memberdayakan guru, manajemen sekolah, rancang ulang sekolah, dan perubahan perencanaan.

Berdasarkan hasil observasi dengan kepala sekolah peneliti melihat bahwa implementasi model MBS di Madrasah Tsanawiyah Swasta TPI Tanjung Putus sudah disosialisasikan dengan baik pelaksanaan MBS di MTsS TPI Tanjung Putus. Dapat dilihat bahwa kepala sekolah memiliki wewenang penuh untuk secara aktif serta mandiri mengembangkan dan melakukan berbagai program peningkatan mutu pendidikan sesuai dengan kebutuhan sekolah sendiri dan dapat menerapkan konsep MBS terutama terhadap komponen-komponen sekolah dengan baik dalam rangka MBS tersebut yaitu dalam kurikulum dan program pengajaran, tenaga kependidikan, kesiswaan, keuangan, sarana dan prasarana pendidikan, pengelolaan hubungan sekolah dengan masyarakat serta manajemen pelajaran khusus lembaga pendidikan.

Dengan demikian, sekolah merupakan salah satu bentuk satuan pendidikan. Dalam penelitian ini peneliti akan memfokuskan pembahasan pada bagaimana implementasi model MBS pada Madrasah TsanawiyahSwasta TPI Tanjung Putus tepatnya disekolah MTsS TPI. Disisi lain, studi pendahuluan yang di lakukan oleh peneliti berkaitan dengan pelaksanaan implememtasi model Manajemen Berbasis Sekolah pada Madrasah Tsanawiyah Swasta TPI Tanjung Putus tersebut merupakan salah satu jenjang pendidikan MTsS yang beralamat di Jalan Mesjid Raya No. 305 
Tanjung Putus merupakan salah satu sekolah yang mencoba mengimplementasikan model MBS.

Madrasah Tsanawiyah Swasta TPI Tanjung Putusyang berkaitan dengan manajemen pelaksanaan pembelajaran saat ini. Berdasarkan hasil observasi awal peneliti menemukan data bahwa Madrasah Tsanawiyah SwastaTPI Tanjung Putus sudah dapat menerapkan Manajemen Berbasis Sekolah (MBS). Hal ini berdasarkan kepala sekolah Madrasah Tsanawiyah SwastaTPI Tanjung Putus memiliki wewenang penuh untuk secara aktif serta mandiri mengembangkan dan melakukan berbagai program peningkatan mutu pendidikan dapat keberadaan disekolahnya.Menurutnya indikator terlaksananya Manajemen Berbasis Sekolah (MBS) pada Madrasah TsanawiyahSwasta TPI Tanjung Putus diantaranya:

1. Perencanaan evaluasi pada Madrasah Tsanawiyah SwastaTPI Tanjung Putus sudah dicapai dalam kenyataan untuk mencapai tujuan sekolah yang di inginkan.

2. Kurikulum dan sistem pembelajaran pada Madrasah Tsanawiyah Swasta TPI Tanjung Putus meliputi kegiatan perencanaan, pelaksanaan, dan penilaian, serta keseluruhan proses penyelenggaraannya yang bertujuan agar seluruh kegiatan pembelajaran terlaksana secara berhasil guna dan berdayaguna dan sudah menggunakan kurikulum KTSP dan mengunakan strategi pembelajaran Contextual Teaching and Learning (CTL).

3. Ketenagaan pada Madrasah Tsanawiyah SwastaTPI Tanjung Putus secara efektif dan efesien untuk mencapai hasil yang optimal namun tetap dalam kondisi yang menyenangkan. Sehubungan dengan itu, fungsi personalia yang harus dilaksanakan pimpinan adalah menarik, mengembangkan, menggaji, dan memotivasi personil guna mencapai tujuan sistem, membantu anggota mencapai posisi dan standar prilaku, serta menyelaraskan tujuan individu dan organisasi.

4. Sarana dan Prasarana Pedidikan pada Madrasah Tsanawiyah Swasta TPI Tanjung Putus sudah lengkap, tetapi kurang dilengkapi dengan sarana pendukung.

5. Keuangan pada Madrasah Tsanawiyah Swasta TPI Tanjung Putus masih ada kendala disebabkan karena belum masih dialokasikan menurut dana Daftar Isian Pelaksanaan Anggaran (DIPA) tahun 2011 masih menetapkan 5400/tahun anak, sementara dari dinas pendidikan sudah menetapkan 250.000 / tahun anak sehingga bangunan gedung dan sarana dan prasarana pendidikan belum memadai dari 
Departemen Agama untuk sekolah Madrasah Tsanawiyah Swasta TPI Tanjung Putus.

6. Kegiatan kesiswaan Madrasah Tsanawiyah Swasta TPI Tanjung Putus bertujuan untuk mengatur berbagai kegiatan dalam bidang kesiswaan agar kegiatan pembelajaran disekolah dapat berjalan lancar tertib dan teratur, serta mencapai tujuan pendidikan disekolah. Untuk mewujudkan tujuan tersebut, bidang manajemen kesiswaan sedikitnya memiliki tiga tugas utama yang harus diperhatikan yaitu penerimaan siswa baru, kegiatan kemajuan belajar serta bimbingan dan pembinaan disiplin.

7. Hubungan sekolah dengan masyarakat pada Madrasah TsanawiyahSwasta TPI Tanjung Putus untuk mengembangkan pemahaman masyarakat terhadap Madrasah, menilai program madrasah, mempersatukan orang tua siswa dan guru dalam memenuhi kebutuhan-kebutuhan peserta didik, mengembangkan kesadaran tentang pentingnya pendidikan madrasah dalm era globalisasi, membangun dan memelihara kepercayaan masyarakat terhadap Madrasah, memberitahu masyarakat tentang pekerjaan madrasah dan mengerahkan dukungan dan bantuan bagi pemeliharaan dan peningkatan program madrasah.

8. Iklim sekolah pada Madrasah Tsanawiyah Swasta TPI Tanjung Putus sebagai satuan pendidikan yang bertugas dan bertanggung jawab melaksanakan proses pembelajaran, tidak hanya bertugas mengembangkan ilmu pengetahuan, keterampilan, dan sikap tetapi harus menjaga dan meningkatkan kesehatan jasmani dan rohani peserta didik dan tertib dalam proses pembelajaran.

Berdasarkan hasil observasi terbaru, peneliti sudah menemukan data tentang pelaksanaan Manajemen Berbasis Sekolah (MBS) dilihat dari pelaksanaan fungsifungsi manajeman terhadap seluruh kegiatan pendidikan pada Madrasah Tsanawiyah TPI Tanjung Putus, tetapi belum sepenuhnya menerapkan Manajemen Berbasis Sekolah (MBS) pada Madrasah Tsanawiyah Swasta TPI Tanjung Putus yaitu sarana dan prasarana pendidikan dan keuangan. Adapun fungsi-fungsi manajemen tersebut meliputi perencanaan, organisasi, pelaksanaan dan pengawasan (POAC).

Dalama hal ini peneliti merasa tertarik untuk melakukan penelitian dengan judul: Implementasi Model Manajemen Berbasis Sekolah (MBS) Pada Madrasah Tsanawiyah Swasta TPI Tanjung Putus. 


\section{METODOLOGI PENELITIAN}

\section{A. Tujuan Khusus Penelitian}

Secara khusus penelitian ini bertujuan untuk mengetahui dan menemukan :

1. Persepsi kepala sekolah tentang penerapan model MBS pada Madrasah Tsanawiyah Swasta TPI Tanjung Putus.

2. Pola kepemimpinan kepala sekolah dalam MBS di Madrasah Tsanawiyah Swasta TPI Tanjung Putus.

3. Penerapan fungsi manajemen dalam kegiatan - kegiatan pendidikan di Madrasah Tsanawiyah Swasta TPI Tanjung Putus.

4. Model MBS dalam peningkatan manajemen pendidikan Madrasah Tsanawiyah Swasta TPI Tanjung Putus.

\section{B. Pendekatan Penelitian}

Penelitian ini menggunakan pendekatan kualitatif naturalistik. Pemilihan metode ini didasarkan atas pertimbangan bahwa yang hendak dicari adalah data yang akan memberikan gambaran dan melukiskan realita sosial yang lebih kompleks sedemikian rupa menjadi yang konkrit. Situasi sosial yang sesuai konteks dilukiskan sampai pada penemuan makna perilaku para aktor yaitu Kepala sekolah mengelola sekolah dalam era otonomi daerah.

Bahwa penelitian kualitatif menghasilkan deskripsi/uraian berupa kata-kata tertulis atau lisan dari perilaku para aktor yang dapat diamati dalam suatu situasi sosial. Selanjutnya dalam penelitian ini peneliti berusaha memahami makna perilaku sekolah di MTsS TPI Tanjung Putus.

Penelitian kualitatif memiliki sejumlah ciri-ciri dengan memadukan pendapat Bogdan dan Biklen serta Lincoln dan Guba mengajukan sebelas ciri penelitian kualitatif yaitu ${ }^{2}$ :

1) Penelitian kualitatif melakukan penelitian pada latar alamiah atau pada konteks dari suatu keutuhan.

2) Dalam penelitian kualitatif peneliti sendiri atau dengan bantuann orang lain merupakan instrumen, sehingga setiap saat dapat menyesuaikan dengan kondisi-kondisi dilapangan.

3) Penelitian kualitatif menggunakan metode kualitatif dengan beberapa pertimbangan. Pertama, menyesuaikan metode kualitatif lebih mudah bila

\footnotetext{
${ }^{2}$ Ibid, hlm. 8-13
} 
berhadapan dengan kenyataan lain. Kedua, metode ini menyajikan secara langsung hakikat hubungan peneliti dengan respon. Ketiga, metode ini lebih peka dan mudah menyesuaikan diri.

4) Penelitian ini menggunakan analisis data secara induktif.

5) Penelitian ini menghendaki arah bimbingan penyusunan teori subtantive yang berasal dari data.

6) Data yang dikumpulkan berupa kata-kata dan bukan angka-angka sehingga menghasilkan analisis berupa uraian.

7) Penelitian ini lebih mementingkan proses daripada hasil.

8) Menghendaki ditetapkannya batas dalam penelitian atas dasar fokus yang menjadi masalah penelitian.

9) Adanya kriteria khusus untuk keabsahan data.

10) Penelitian kualitatif desain terus-menerus dan menyesuaikannya dengan kenyataan dilapangan, didesainnya tidak ketat dan tidak kaku serta lapangan senantiasa berpengaruh terhadap pola penelitian.

11) Hasil penelitian dirundingkan dan disepakati bersama. Peneliti kualitatif lebih menghendaki agar pengertian dan hasil interpretasi yang diperoleh dirundingkan dan disepakati dengan orang yang dijadikan sumber data.

Pendekatan kualitatif merujuk kepada penelitian yang luas terhadap penelitian yang menghasilkan data deskriptif yang berupa kata-kata dan perilaku orang yang dapat diobservasi dari lisan maupun tulisan.

\section{Sumber Data Penelitian}

Subjek penelitian ini diarahkan pada pencarian data dari kepala sekolah, wakil kepala sekolah, guru, maupun staf di MTsS TPI Tanjung Putus. Pencarian data dimulai dari kepala sekolah sebagai informan kunci (key informance), kemudian informan berikutnya ditentukan berdasarkan atas petunjuk kepala sekolah. Pencapaian data akan dihentikan manakala tidak ada lagi variasi data yang muncul. Dengan demikian jumlah informan penelitian ini tidak ditentukan secara pasti tergantung pada tingkat keperluan data yang diperlukan

\section{Alat Pengumpulan Data}

Sesuai dengan bentuk pendekatan penelitian kualitatif dan sumber data yangakan digunakan, maka teknik pengumpulan data yang digunakan adalah dengananalisis dokumen, observasi dan wawancara. Untuk mengumpulkan data 
dalamkegiatan penelitian diperlukan cara-cara atau teknik pengumpulan data tertentu,sehingga proses penelitian dapat berjalan lancar.

Metode pengumpulan data yang digunakan untuk mengumpulkan datadalam penelitian kualitatif pada umumnya menggunakan teknih observasi, wawancara, dan studi dokumenter,

\section{HASIL DAN PEMBAHASAN PENELITIAN}

Ada dua temuan utama dalam penelitian ini yang perlu dibahas, yaitu : Temuan umum dan temuan khusus. Temuan umum menunjukkan tentang keadaan atau gambaran umum tentang lokasi penelitian serta tenaga pendidik, siswa, sarana dan kurikulum dan temuan khusus menunjukkan tentang hasil wawancara dengan kepala sekolah dan guru.

Manajemen berbasis sekolah merupakan suatu model manajemen yang memberikan otonomi lebih besar kepada sekolah dan mendorong pengambilan keputusan partisipatif yang melibatkan secara langsung semua warga sekolah guru, siswa, kepala sekolah, karyawan, orang tua dan masyarakat untuk meningkatkan mutu sekolah berdasarkan kebijakan pendidikan nasional. Persiapan Kepala SekolahDalam Meningkatkan Mutu Pendidikan Melalui Manajemen BerbasisSekolah (MBS) (Studi Kualitatif di SMPN 5 Bandar Lampung).

Perubahan peran guru yang tadinya sebagai penyampai pengetahuan dan pengalihan pengetahuan dan pengalih keterampilan, serta merupakan satu satunya sumber belajar, berubah peran menjadi pembimbing, pembina, pengajar, dan pelatih. Dalam kegiatan pembelajaran, guru akan bertindak sebagai fasilisator yang bersikap akrab dengan penuh tanggung jawab, serta memperlakukan peserta didik sebagai mitra dalam menggali dan mengolah informasi menuju tujuan belajar mengajar yang telah direncanakan.

Beratnya tanggung jawab bagi guru menyebabkan pekerjaan guru harus memerlukan keahlian kusus.Untuk itu pekerjaan guru tidak dapat dilakukan oleh sembarang orang diluar bidang pendidikan, sehingga profesi guru paling mudah terkena pencemaran. Sekali guru berbuat salah maka akan berdampak terhadap dunia pendidikan, demikian pula sekali guru salah mengajarkan ilmu kepada anak didiknya, maka akan berdampak dan berimbas kepada satu generasi. 
Guru dalam melaksanakan tugas profesinya dihadapkan pada berbagai pilihan, seperti cara bertindak bagaimana yang paling tepat, bahan belajar apa yang paling sesuai, metode penyajian bagaimana yang paling efektif, alat bantu apa yang paling cocok, langkah-langkah apa yang paling efisien, sumber belajar mana yang paling lengkap, sistem evaluasi apa yang paling tepat, dan sebagainya.

Guru sebagai pelaksana tugas otonom, guru diberikan keleluasaan untuk mengelola pembelajaran, apa yang harus dikerjakan oleh guru, dan guru harus dapat menentukan pilihannya dengan mempertimbangkan semua aspek yang relevan atau menunjang tercapainya tujuan. Dalam hal ini guru bertindak sebagai pengambil keputusan.

Guru sebagai pihak yang berkepentingan secara operasional dan mental harus dipersiapkan dan ditingkatkan profesionalnya, karena hanya dengan demikian kinerja mereka dapat efektif, apabila kinerja guru efektif maka tujuan pendidikan akan tercapai. Yang dimaksud dengan profesionalisme disini adalah kemampuan dan keterampilan guru dalam merencanakan, melaksanakan pengajaran dan keterampilan guru merencanakan dan melaksanakan evaluasi hasil belajar siswa.

Mengingat pentingnya prfesionalisme guru dalam pencapaian tujuan pendidikan utamanya pada skala tingkat institusional, maka perluadanya pelatihan dan profesionalisme guru, sehingga dapat diperoleh hasil penelitian yang bisa dijadikan masukan dalam membuat dan melaksanakan kebijakan di bidang pendidikan terutama pada tingkat sekolah dasar sampai menengah baik negeri maupun swasta.

Standar mutu kepala sekolah terdiri dari enam standar; dan standar mutu pengawas sekolah terdiri dari standar (1) Visi pendidikan; (2) Budaya sekolah; (3) Manajemen; (4) Komunikasi dan Kolaborasi dengan masyarakat; (5) Sikap

Keteladanan, Kejujuran, Keadilan, dan Etika Profesi; (6) Lingkungan Politik, Sosial, Hukum, Ekonomi, dan Budaya; (7) Program Instruksional; dan (8) Implementasi Kebijakan (Abu Sijak, 2006. "Standar Mutu Sekolah, Kepala Sekolah, dan Pengawas Sekolah")

Banyak pakar dan pemerhati pendidikan menyumbangkan pikirannya untuk mengkaji model MBS yang cocok dengan kondisi negeri ini. Namun jarang sekali yang menyinggung masalah isi (content) yang tak lain merupakan hakikat desentralisasi itu sendiri. Hakikat desentralisasi pendidikan adalah "apa dan kepada siapa" (what and to whom) dan bukan aturan-aturannya (regulation). 
Kepala sekolah mempunyai dua peran utama, pertama sebagai pemimpin institusi bagi para guru, dan kedua memberikan pimpinan dalam manajemen. Pembaharuan pendidikan melalui manajemen berbasis sekolah dan komite sekolah yang diperkenalkan sebagai bagian dari desentralisasi memberikan kepada kepalasekolah kesempatan yang lebih besar untuk menerapkan dengan lebih mantap berbagai fungsi dari kedua peran tersebut

Reformasi pendidikan di banyak negara dimulai pada dekade 1980- an. Banyak sekolah di Amerika Serikat, Kanada dan Australia yang berhasil menerapkan desentralisasi pendidikan dengan model Manajemen Berbasis Sekolah.

Malalui Manajemen Berbasis Sekolah sekolah memiliki kewenangan dalam pengambilan keputusan yang terkait langsung dengan kebutuhan-kebutuhan sekolah.

\section{KESIMPULAN}

Berdasarkan uraian dan penelitian serta analisa data yang dilakukan pada MTs TPI Tanjung Putus mengenaiImplementasi Model Manajemen Berbasis Sekolah (MBS) maka dapat ditarik kesimpulan sebagai berikut:

1. Persepsi kepala sekolah tentang penerapan model Manajemen Berbasis Sekolah merupakan bahwa model Manajemen Berbasis Sekolah (MBS) disekolah telah berhasil dilaksanakan karena adanya kemauan yang kuat, kemampuan dan kerjasama dari berbagai pihak khususnya warga sekolah dalam mewujudkan keinginan untuk melaksanakan peningkatan mutu pendididikan disekolah.

2. Pola kepemimpinan kepala sekolah dalam Manajemen Berbasis Sekolah (MBS) disekolah merupakan pola kepemimpinan dalam konteks manajemen pendidikan berbasis sekolah merupakan suatu keharusan yang tidak bisa ditawar, karena dalam hal kepemimpinan kepala sekolah juga perlu memahami konsep dasar manajemen dan kepemimpinan, untuk itu pemimpin menyertakan kepada guru-guru dan pegawai dalam mengambil keputusan tentang kebijakankebijakan disekolah dengan memberikan kesempatan kepada guru-guru dan pegawai untuk memberikan saran dan kritikan, sehingga guru dan pegawai menganggap bahwa pola kepemimpinan yang digunakan adalah kepemimpinan demokratis.

3. Penerapan fungsi manajemen dalam kegiatan-kegiatan pendidikan disekolah merupakan bahwa fungsi manajemen sudah diterapkan dalam kegiatan- 
kegiatan pendidikan disekolah, karena sudah mencakup fungsi manajemen dalam perencanaan, pengorganisasian, pelaksanaan, dan pengawasan.

4. Model Manajemen Berbasis Sekolah dalam peningkatan manajemen pendidikan disekolah merupakan konsep sensional yaitu perumusan visi, misi dan program yang beroriantasi pada unggulan dalam mencapai stándar pendidikan.Dan adanya kerjasama seluruh personil sekolah dalam melakukan berbagai program peningkatan mutu pendidikan sesuia dengan kebutuhan sekolah sendiri sudah dapat meningkatkan manajemen pendidikan.

\section{DAFTAR PUSTAKA}

Dakir, Perencanaan dan Pengembangan Kurikulum, Jakarta : Rineka Cipta 2004

Danim, Sudarnam, Visi Baru Manajemen Sekolah, Jakarta: Bumi Aksara, 2006

Departemen Agama, Al-qur'an dan Terjemahan,Al-baqarah ayat 30

Mulyasa,E manajemen Berbasis Sekolah Konsep, Strategi,dan Implementasi, Remaja Rosdakarya, 2002

Nurkolis, Manajemen Berbasis Sekolah:Teori,Model,dan Aplikasi,Jakarta: Grasindo,2003

Siahaan, Amiruddin, dkk, Manajemen Pendidikan Berbasis Sekolah, Ciputat: Quantum Teaching,2006

Sujanto, Bedjo, Manajemen Pendidikan Berbasis Sekolah, Jakarta: Sagung Seto, 2007

Usman, Husaini, Manajemen Teori, Praktik, dan Riset Pendidikan, Jakarta: Bumi Aksara,2006

Wahjosumidjo, Kepemimpinan Kepala Sekolah:Tinjauan Teoritik dan Permasalahannya,PT.Raja Grafindo Persada,Jakarta,1999 